\title{
LAMPROITIC(?) DIATREMES IN THE GOLDEN AREA OF THE ROCKY MOUNTAIN FOLD AND THRUST BELT, BRITISH COLUMBIA, CANADA.
}

McCallum, M.E.

Department of Earth Resources, Colorado State University, Fort Collins, CO 80523, USA.

During the last 15 years approximately two dozen diatremes have been recognized north of Golden, British Columbia in a northwest trending belt that roughly parallels the B.C.-Alberta province boundary and extends about 55km between the Campbell and Columbia Icefields (Pell, 1987) (Fig. 1). The diatremes are situated within the Rocky Mountain Fold and Thrust Belt and their emplacement relationship to Columbian and Iaramide deformation is uncertain. Thirteen discrete "pipes" have been mapped at the Larry, Jack, Mike and Mark localities (McCallum, 1990) and all penetrate a folded and locally faulted sequence of Cambro-Ordovician sedimentary units (Fig. 2). The pipes typically are lensatic, parallel or subparallel locally prominent axial plane cleavage in host rocks, and generally are penetrated by a coincident set of cleavage or foliation planes. One pipe is situated in the core of an anticlinal fold (Fig. 3) and another appears to have been emplaced along a thrust fault, although the latter may be a lensatic, fault emplaced block of diatreme breccia. Tectonic setting suggests that most of these diatremes post-dated folding associated with the Columbian orogeny (younger than $95 \mathrm{ma}$ ), and may have been as late as the climax of the Laramide orogeny (60 ma). The well developed cleavage, foliation and local shearing of diatreme breccia indicate at least moderate post intrusion deformation which may have been related to late stage orogenic activity (post folding) or possibly in part in response to post-orogenic relaxation processes. However, several workers (e.g. Pell, 1986, 1987; Ijewliw and Schulze, 1989) postulate a Iate Silurian-Early Devonian age for these pipes and preliminary $\mathrm{Rb} / \mathrm{Sr}$ ratios established from mica separates from the Larry dike complex (Pell, written commun., 1989, Smith, written commun., 1990) support this contention. Apparent inconsistencies between structural relationships and age dates are yet to be resolved.

Diatreme facies tuffisitic breccias predominate and these range from clast to matrix supported, very coarse (block) to fine-grained (lapilli to lapilli-ash) varieties. A locally prominent "sandy" tuffisitic breccia phase is characterized by abundant rounded to subrounded quartz grains (most $<0.5 \mathrm{~mm}$, commonly comprising $>40 \%$ of rock) and is texturally similar to sandy tuff phases described at the Argyle and Prairie creek lamproite pipes in Australia and Arkansas respectively. Breccia clasts are predominantly host rock sediments, but phyllite, schist, gneiss, granitoids, gabbro, diorite, pyroxenite, basalt and lamprophyre fragments are abundant locally. Ieucite(?) and or sanidine bearing lamproite(?) clasts are present in some breccia phases at the Jack diatreme. Mineral clasts (other than quartz) and breccia groundmass material generally are difficult to identify due to extensive alteration. However, based on pseudomorphic form, alteration products, and rare unaltered to partially altered grains the presence (or former presence) of variable amounts of olivine, pyroxene, amphibole, sanidine, leucite(?), perovskite, spinel (chromite?), and devitrified glass has been reasonably well established. Some phases contain abundant fresh phlogopite and/or sanidine. Iocally present hypabyssal facies material occurs in irregular zones, narrow crosscutting dikes or xenolithic blocks, and although also generally intensely altered, appears to be mineralogically'similar to breccia matrix material. Four small diamonds have been reported; three from the Jack diatreme and one from the Mark 1 pipe. 
Preliminary chemical data (Fipke, written commun., 1990) for breccia matrix samples from the Jack diatreme indicate a distinctly ultrapotassic nature (ca. 10wt\% $\mathrm{K}_{2} \mathrm{O}$ ), high $\mathrm{K}_{2} \mathrm{O} / \mathrm{Na}_{2} \mathrm{O}$ ratios (ca. 67) and moderately high $\mathrm{SiO}_{2}$ (ca. $52 \mathrm{wt} \%$ ). These data coupled with the presence of sanidine, high

Ti phlogopite, Sr barite, Sr apatite, glass and pseudomorphs after leucite, olivine, pyroxene and amphibole provide strong evidence to classify the Jack tuffisitic breccia as lamproite although enrichment in incompatible elements (e.g. ca. $200 \mathrm{ppm} \mathrm{Zr}$ and $900 \mathrm{ppm} \mathrm{Ba}$ ) is lower than average for lamproites. Furthermore, whole rock $\mathrm{Mg} /(\mathrm{Mg}+\mathrm{Fe}$ ) ratios of two samples fall well within the lamproite field, low $\mathrm{Na}_{2} \mathrm{O}(0.28-1.05$ wt\%) and high $\mathrm{MgO}+\mathrm{F} \in \mathrm{O}_{\mathrm{T}}(0.96-2.35 \mathrm{wt} \%)$ contents of sanidine are characteristic of lamproites as are $\mathrm{Al}_{2} \mathrm{O}_{3}$ levels in phlogopite $\left(1-14 \mathrm{wt} \% \mathrm{Al}_{2} \mathrm{O}_{3}\right)$. Limited chemical data for breccia phases from the Larry, Mark and Mike diatremes indicate highly variable compositions and considerably lower levels of alkali enrichment (ca. 2-7wt\% $\mathrm{K}_{2} \mathrm{O}$ ) than Jack diatreme material, and concentrations of incompatible elements (e.g., $\mathrm{Zr}, \mathrm{Nb}$ and $\mathrm{Ba}$ ) are well below those characteristic of lamproites. However, $\mathrm{K}_{2} \mathrm{O} / \mathrm{Na}_{2} \mathrm{O}$ ratios are high (36 to 63), and, although extensively altered, mineral assemblages appear to be fairly similar to those at the Jack pipe. All appear to lack primary plagioclase, melilite, melanite and feldspathoids other than leucite. Allowing for the problems inherent to analyzing diatreme breccias and considering petrographic evidence that suggests a possible lamproitic affinity, the Larry, Mark and Mike tuffisitic breccias are tentatively classified as lamproitic, although an alkaline lamprophyre (sannaite) designation might be appropriate.

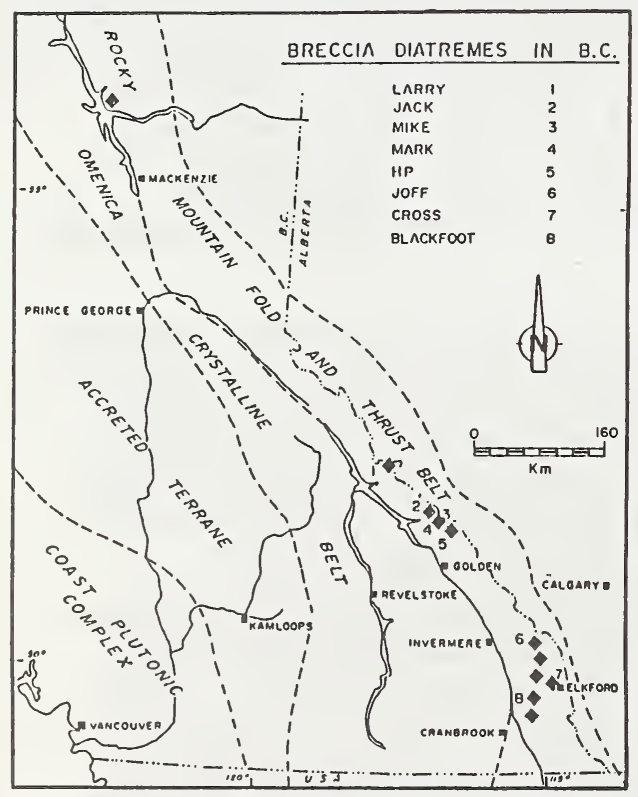

FIGURE 1. Location of the Golden and Elksford area diatremes, southeastern British Columbia. Modified after Pell (1986). 


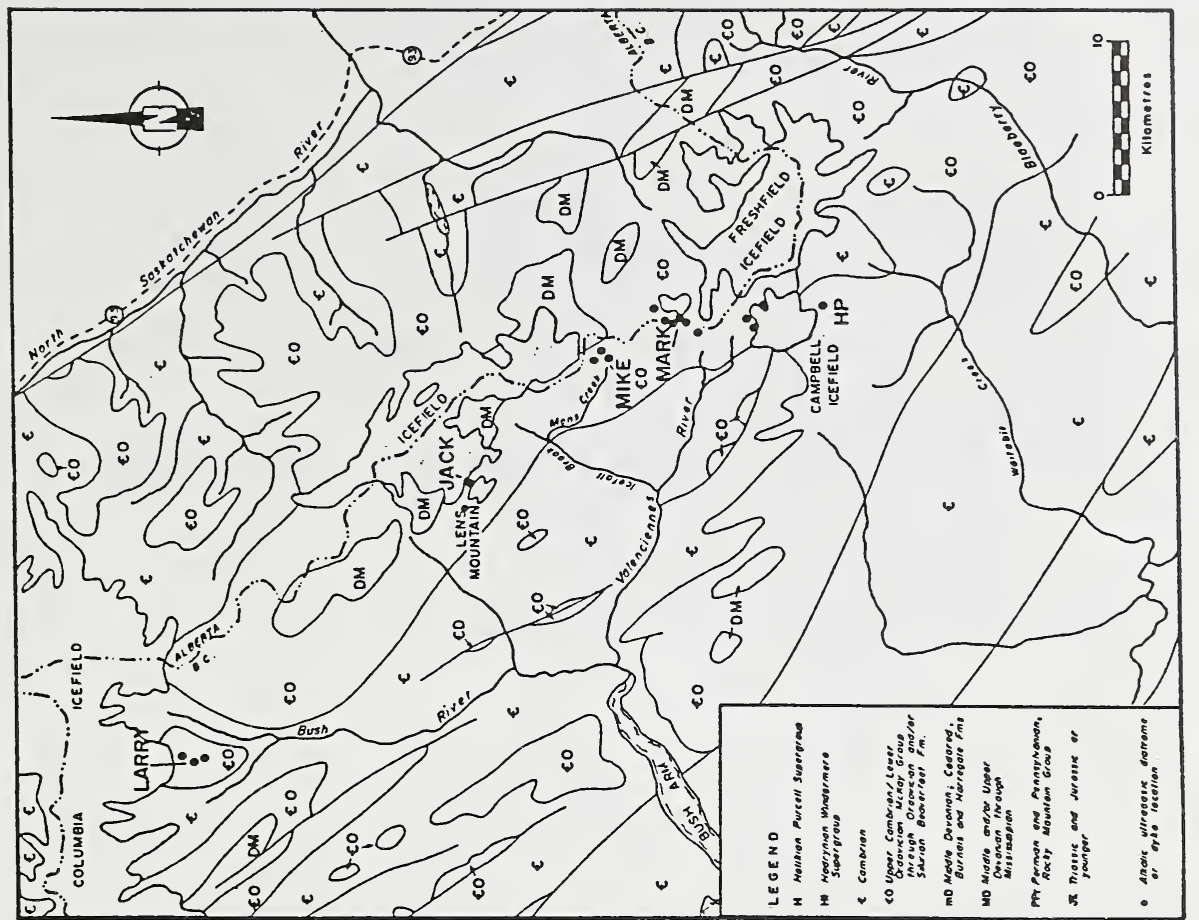

वీ.

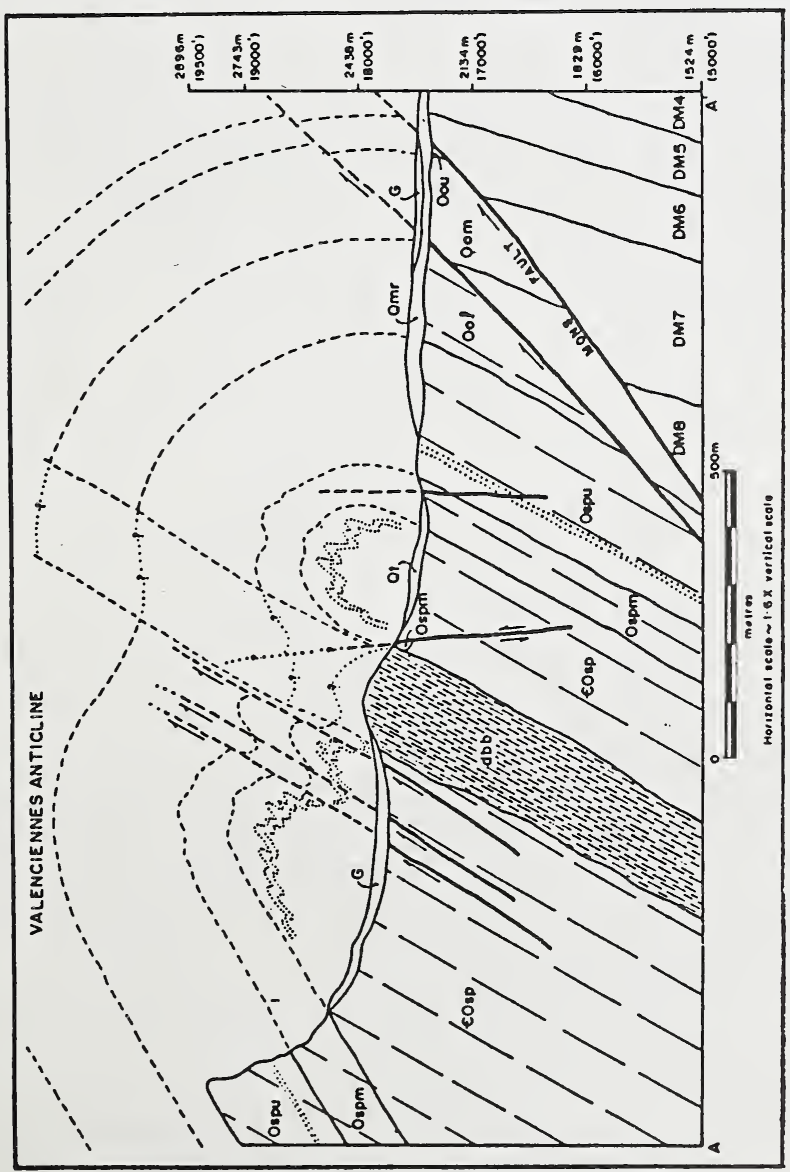

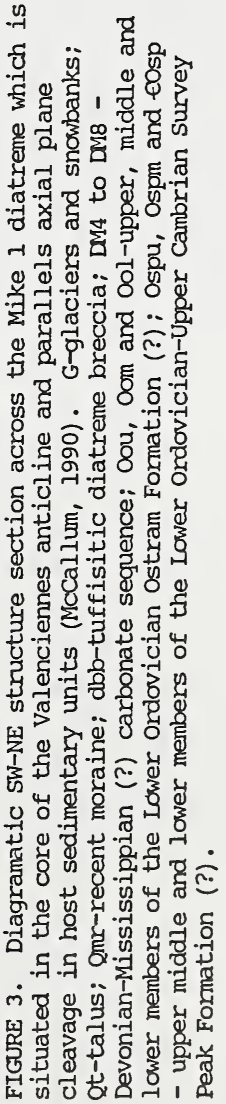




\section{REFERENCES}

Bergman, S.C. (1987) Lamproites and other potassium-rich igneous rocks: a review of their occurrence, mineralogy and geochemistry. In J.G. Filton and B.G.J. Upton eds., Alkaline igneous rocks, Special Publication of the Geological Society of Iondon 30, p. 103-190.

Ijewliw, O.J. and Schulze, D.J. (1989) The Golden cluster of diatremes and dikes. British Columbia Ministry of Energy, Mines and Petroleum Resources, Geological Field work, 1988, Paper 1989-1, p. B39-B46.

McCallum, M.E. (1990) Geology of the Jack, Lamy, Mark and Mike diatremes, Golden Area, British Columbia. In, The development of advanced technology to distinguish between productive diamondiferous and barren diatremes, Part II, p. 138-184, 229-321. Canadian Geological Survey Open File Report 2124.

Pell, J. (1986) Diatreme breccias in British Columbia. British Columbia Ministry of Energy, Mines and Petroleum Resources, Geological Fieldwork, 1985, Paper 1986-1, p. 243-253.

Pell, J. (1987) Alkalic ultrabasic diatremes in British Columbia. British Columbia Ministry of Energy, Mines and Petroleum Resources, Geological Fieldwork, 1986, Paper 1987-1, p. 259-272. 